\title{
プラズマイオン注入を目的とした新しいモデュレータ動作 ヘのターゲット面積およびターゲット位置の効果
}

$\begin{array}{lrrrl}\text { 正 } & \text { 員 } & \text { 行村 } & \text { 建 } & \text { (同志社大学) } \\ \text { 学 生 員 } & \text { 寺本 } & \text { 智之 } & \text { (同志社大学) } \\ \text { 学 } & \text { 生員 } & \text { 久世 } & \text { 英司 } & \text { (同志社大学) } \\ \text { 正 } & \text { 員 } & \text { 松永 } & \text { 浩一 } & \text { (ハイデン研究所) }\end{array}$

\section{Effect of target area and position on electrical characteristics of a new type of PBII Modulator adaptable to a wide range of load resistance}

\author{
Ken Yukimura, Member, Tomoyuki Teramoto, Student Member, Eiji .Kuze, Non Member \\ (Doshisha University), Koichi Matsunaga, Member (Haiden Laboratory Inc.)
}

\begin{abstract}
This article describes a preliminary test results obtained by a newly-developed pulse modulator which is independent on the plasma parameters and the substrate configuration. The modulator will be employed for Plasma-based Ion Implantation (PBII). The typical data obtained are an output voltage of $5 \mathrm{kV}$ and a pulse length of 10 microseconds, which is independent on the target diameter $(60 \mathrm{~mm}$ and $100 \mathrm{~mm})$ and the distance $(150 \mathrm{~mm}$ and $400 \mathrm{~mm})$ between the target and metal arc source. The voltage waveform is in a rectangular shape with the rise and fall times less than 1 microsecond due to a closing switch which is newly set in parallel with the target as a modulator load. In a conventional modulator with a transformer for raising up the primary voltage, the same parameter surveys have been carried out and have strongly affected by the target diameter and distance due to the high circuit impedance.
\end{abstract}

キーワード : プラズマイオン注入,PBII,PIII,PSII, モデュレータ

\section{1.まえがき}

プラズマイオン注入の要素技術としては(1)プラズマ発 生技術, (2)モデュレー夕技術, (3)接続線技術に大別され る。本研究は(2)モデュレー夕技術に関連する。モデュレー 夕技術の中枢的な要素は(2-1)スイッチ技術, (2-2)波形成 形技術，(2-3)保護技術に分けられる。

モデュレータ主回路のスイッチを閉とすることにより電 流が流れる。スイッチのターンオン特性が出力波形の立方 上がり特性を左右する。可能な限り早い時間のうちにオン させイオンシースの形成によりイオンを加速する。閉ス イッチ素子としては半導体素子や真空管をはじめとしてサ イラトロンなども用いられる。

接続線技術はモデュレータ出力とターゲットの接続技術 であり,電流導入端子における絶縁技術も含まれる。接続 に伴う漂遊容量の減少が重要である。モデュレータの出力 エネルギーの一部は漂遊容量を充電し，効率の低下を招く。 モデュレータ技術はプラズマイオン注入の基幹技術であ る。矩形パルス電圧の発生を目的とし,イオンを線形加速
する。モデュレータ出力にターゲットおよびプラズマが直 列に接続される。負荷であるプラズマやイオンシースのイ ンピーダンスはプラズマ密度はもとより,ターゲット形状 (面積, 体積, 曲率など)により変わる。

プラズマ中にあるターゲットに負電圧が印加されると質 量の小さい電子が排斥され、イオンシースが形成される。 電子の応答時間は電子プラズマ振動周波数の逆数程度の時 間オーダであり、ナノ秒のオーダーで排斥される1。この ように電子の応答時間は高速であるため,初期の夕ーゲッ 卜印加電圧波形やターゲット電流波形にはスイッチ素子の ターンオン時間が大きく影響する。

一方, 電圧の立下り時 (所定のパルス幅の設定によりス イッチ素子は強制的にオフされる)は負荷インピーダンス が影響する時間領域である2。負荷とはターゲット周囲に 形成されるイオンシースキャパシタンスや抵抗を指す。イ オンシース容量およびターゲットや電流導入端子などの接 続に伴う漂遊容量はモデュレー夕出力電圧值に充電されて おり,スイッチがオフとなることより回路抵抗およびシー 不抵抗などを通して放電する。放電電流は充電電流とは逆 方向に流れるため,反転電流として観測されることもある 
2)。放電の時定数はルsオーダーに達し，電圧波形に波尾を 生ずる。電圧波尾の領域はスパッ夕の領域に達したり,高 繰り返しパルス電圧印加時には，電圧が十分にゼロに復帰 しないまま電圧が再印加されることも起こる。後者の場合 ,定常的にターグットの周囲にイオンシースが形成され, 3 次元形状物への均一注入の妨げとなる。このような結果は プラズマイオン注入に好ましい結果をもたらさない。

従来の研究において負荷であるプラズマやイオンシース が印加電圧波形に值接影響し，問題となることは多くの研 究において指摘されている。たとえば，G.Bohm ら ${ }^{3)}$ は負荷 インピーダンスがターゲットの大きさとプラズマパラメー 夕に依存することを指摘した。しかるに従来のモデュレー 夕では、それぞれの応用に対応できるようにモデュレータ との間のインピーダンス整合を取ることは困難であると述

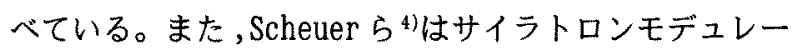
タを用い,ターゲット負荷とパルス成形回路との間のイン ピーダンス不整合により,主パルスとは別の副次パルスの 発生を指摘している。Collins ら ${ }^{5)}$ はモデュレータの特性 が負荷であるプラズマに大きく影響され,シース挙動が変 化することを指摘した上で,結果としてプラズマパラメー タによってはモデュレータの使用電圧に制限が加わること を述べている。

我々は負荷の影䅧を受けない, モデュレータ固有の出力 電圧を夕ーゲットに印加する回路方式を提案する。本研究 では夕ーゲット归加電圧波形について金属蒸気プラズマ源 (直流)とターゲット間の距離およびターゲット面積の影 響を中心としてターゲット印加電圧波形の変化について検 討する。結果として, モデュレータ特性としては, 負荷に 影響されない特性となることを報告する。

\section{2. 回路方式}
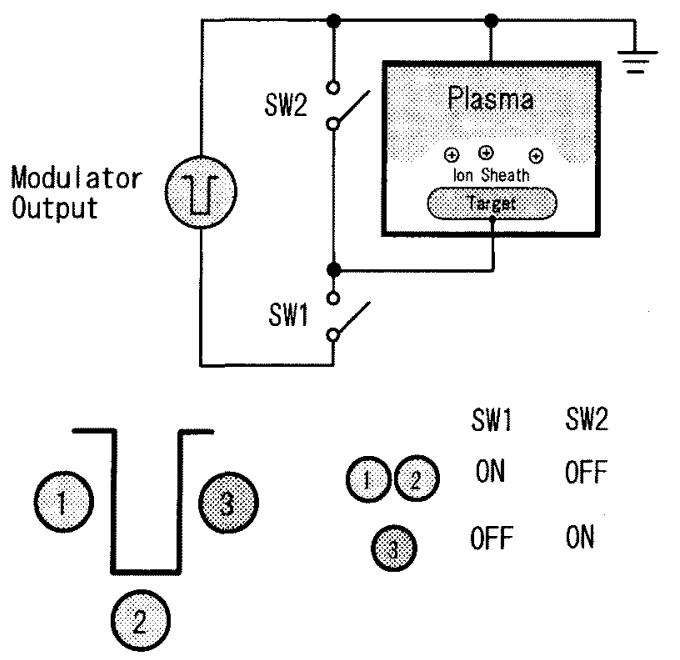

図1新しいモデュレータの基本動作図

Fig.1 A schematic diagram of a new modulator for PBII
モデュレー夕動作の概要を図 1 に示す。図中，左がモ デュレータ出力, 右に真空容器があり、真空容器の内部に ターゲットがある。閉スイッチは2 個設けられている。図 中には2つのスイッチの動作を示す。SW1 はモデュレータ の出力電灰をターゲットに印加するのが目的であり，SW2 は負荷（プラズマおよびイオンシース）に並列に設けられ ており、オフ時の電压を速やかにゼロにするために新たに 設けられている。

ターゲットへのパルス電圧の印加はSW1をオンさせて行 い,所定のパルス幅に達すると,SW1をオフし, 同時にオン 信号を SW2に加える。SW2 がオンすると, 負荷は短絡され るため $1 \mu \mathrm{s}$ 以下の短時間の内に負荷はゼ口電位に達する。 開発されたモデュレータはSW1 とSW2の2つのスイッチ 動作と共にモデュレータの出カインピーダンスを約 $3 \Omega$ と 低くした点にも特徴を持つ。低インピーダンスとするため に, 昇圧のための変圧器を設けていない。このようにして 負荷インピーダンスそのものの影響を受けない定電圧特性 とすることができる。モデュレータの閉スイッチ素子は MOSFET(耐圧 $1600 \mathrm{~V}$, 許容電流 $40 \mathrm{~A}, 10$ 個直列接続)であり, 直流電源(最大出力 $4 \mathrm{~kW}$ )の出力を負荷であるターグットに 直接接続する。したがって, モデュレータの出力インピー

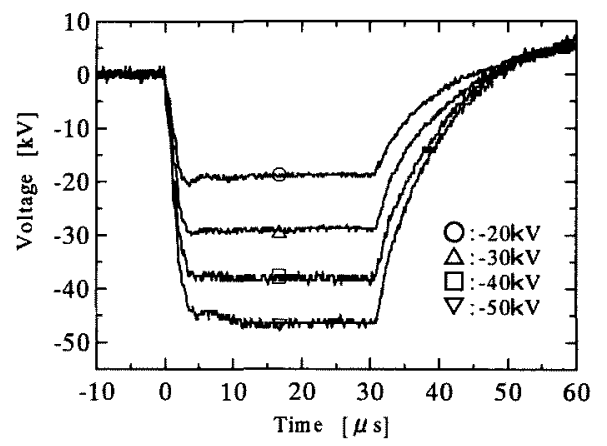

(a) Target applied voltage

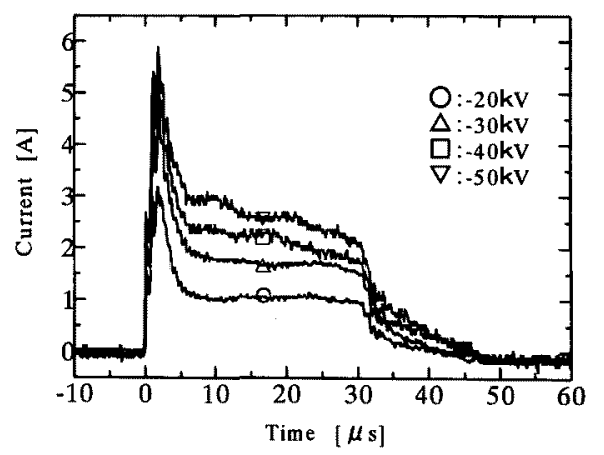

(b)Current through the target

図2 ターゲットへの印加電圧波形とターゲットを流れる電 流波形例(チタン直流プラズマ70A, タ…グットの直径60mm) (3)

Fig. 2 Waveforms of voltage applied to the target and current through the target (Titanium arc current:70A and target diameter:60mm $)^{\hat{i}}$ 


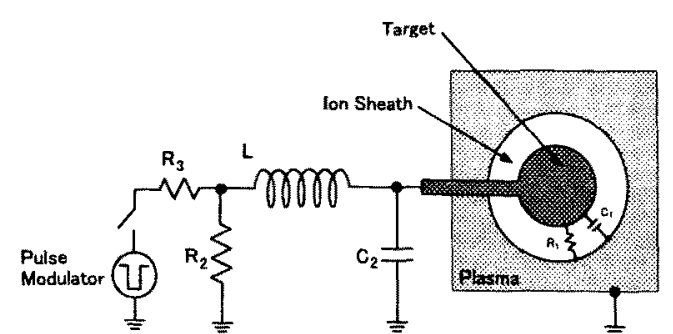

図3ターゲット周囲の等価回路

Fig.3 Equivalent circuit of modulator and target

ダンスは，事実上，閉スイッチ素子のオン時の抵抗(1 個 あたり $0.2 〜 0.3 \Omega)$ みとなり,モデュレータシステムと しての全出力インピーダンスは $3 \Omega$ 以下の小さな值とな る。

本研究において提案している方式は低インピーダンス, オフ時に負荷を短絡する方式であるので，目的とするパル ス電圧をターゲットに䁒加できる特徵を持つ。

\section{3. 従来形モデュレータのターゲット印加電圧 · 電流特} 性

〈3.1〉プラズマおよびイオンシースの影幚 本節では、主ス イッチが1個であり, 昇圧用の変圧器(昇圧比 $1: 3$ )を用い た場合のモデュレー夕を用いたときの電圧,電流特性につ いて㭘討する。

ターゲットに電圧を印加することにより、電圧に波尾が 生ずる例を図 $2{ }^{6)} に$ にす。(a)は電圧、(b)は夕ーゲットを流 れる電流を示す。等価回路を図3に示す。図2 の特性は直 流金属蒸気アークプラズマ(電流70A)にて得られた。設定 されたパルス幅は30 $\mu$ sであるが，図より明らかなように $30 \mu \mathrm{s}$ 以降,電圧がゼロに復㷌するプロセスで, 約 $10 \mu \mathrm{s}$ の時定数を持つ。これはイオンシースおよび漂遊容量の合 成容量 $\mathrm{C}\left(=\mathrm{C}_{1}+\mathrm{C}_{2}\right)$ に充電された電荷がイオンシース挹よび 回路の抵抗 $R\left(=R_{1}+R_{2}\right)$ や昇圧トランスを含むモデュレータ の持つインダクタンスや回路インダクタンスしを通じて放 電する時間を表す。実験で得られた電圧, 電流波形をカー ブフィットして求められた定数は $\mathrm{C}=200 \mathrm{pF}, \mathrm{R}=17 \mathrm{k} \Omega$ ， $\mathrm{L}=7.2 \mathrm{mH}$ である ${ }^{2)}$ 。また、電圧減衰時の等価周波数を $10 \mathrm{kHz}$ とすると,Lの持つインピーダンスは約 $0.5 \mathrm{k} \Omega$ に相当す る。したがって、Cに蓄積された電荷の放出は主としてRを 通じて行われることがわかる。このことはパルス電圧のオ フ時にRの両端(主ラインと接地線の間に存在する)を橋絡 すれば波尾の時定数を小さくすることができる。

プラズマの有無により日加電圧波形が変化する例を図 42)に示す。図はrf(13.56MHz)放電による場合であり，継 続時間1msのバースト波であり，休止期間9ms(デューティ 比 10\%)にて繰り返し運転された。この場合のモデュレー 夕は,一次電圧をパルス変圧器(巻数比1:18)により昇圧し ている。

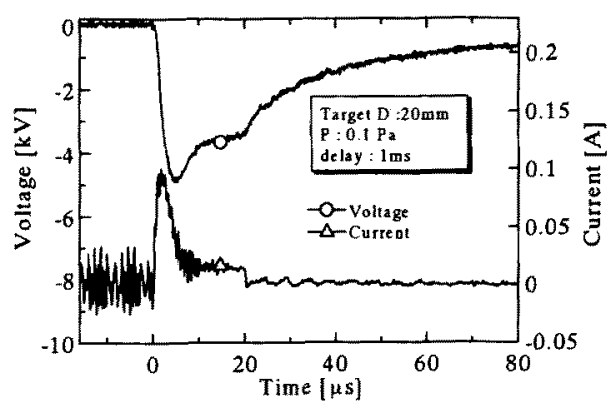

(a)Delay time:0 ms

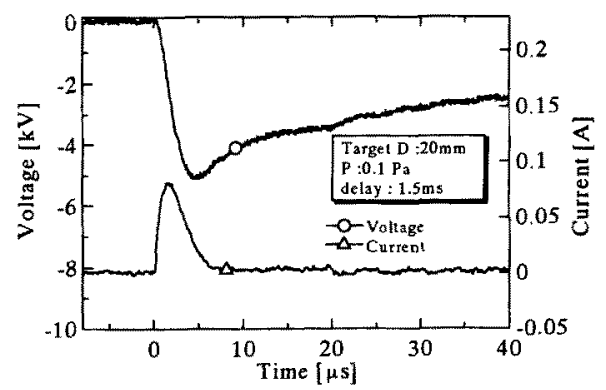

(b) Delay time: $1.5 \mathrm{~ms}$

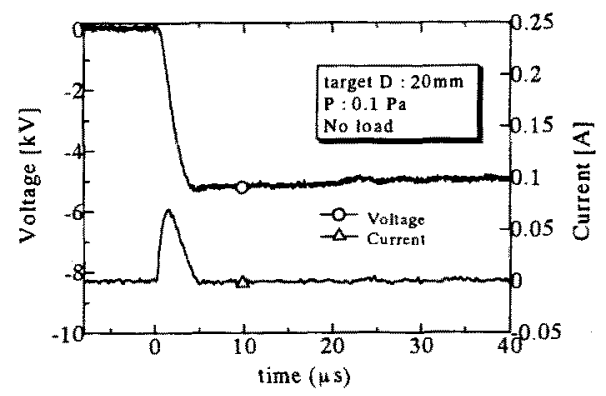

(c)No plasma phase

図 4 プラズマの有無による日加電圧波形の変化

Fig.4 Change of the electrical characteristics around the target with and without plasma

(a)〜 (c)は夕ーゲットに甲加されるパルス電圧のタイミ ングが異なる。(a)はプラズマがターゲットの周囲に存在 し, 図 3 中，C1 とR1にて決定されるシースインピーダン スが低い場合，(b)はいわゆるアフターグローの状態で あって,シースインピーダンスは(a)よりは高く,(c)より は低い領域にある。(a)においてCを200pF と仮定すると， $\mathrm{R}$ は $100 \mathrm{k} \Omega$ 程度と見積もられ，(b)では3〜4倍の值を持つ。 (c)はプラズマがターゲットの周囲に存在しない場合であ り,ターゲット周辺の抵抗はほぼ無限大である。このよう に電圧印加のタイミングによりシースの等価インビーダン スが変化し,立ち下がり部である電圧波尾の特性が大きく 異なることがわかる。スイッチオフ時の印加電圧の立ち下 がりの領域を見ると,プラズマ負荷がある場合には早い立 ち下りであるのに対し,プラズマが薄い(密度が低下する) 状態(図(b))では波尾が長くなる。図(c)はプラズマが存在 しないため，終端開放となり，電圧の降下は見られない。 


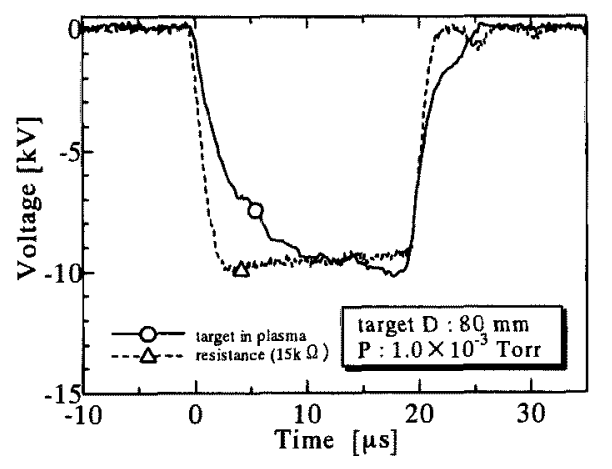

図5ターゲット直径80mmにおけるターゲット印加電圧波形 (アーク源からの距離 $150 \mathrm{~mm}$ )

Fig. 5 Waveform of applied voltage to the target of $80 \mathrm{~mm}$ diameter (Distance between target and arc source: $150 \mathrm{~mm}$ )

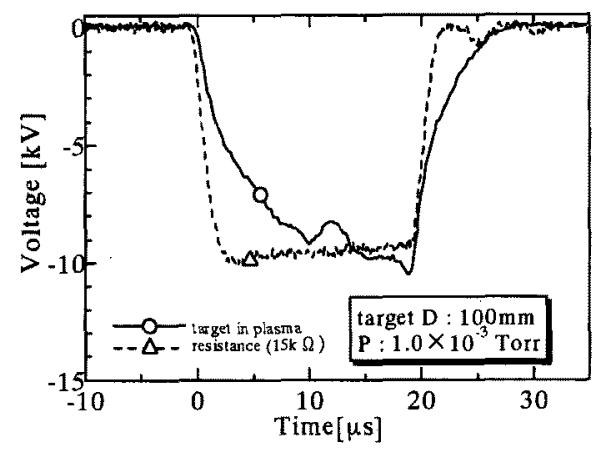

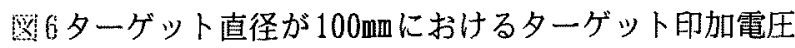
波形(アーク源からの距離 $150 \mathrm{~mm}$ )

Fig. 6 Waveform of applied voltage to the target of $100 \mathrm{~mm}$ diameter (Distance between target and arc source: $150 \mathrm{~mm}$ )

特性の違いは負荷であるターゲット周辺のインビーダンス の大小の結果である。

ターゲット周囲のインピーダンスはターゲットに流れる 電流值にも影響する。初期にピークに達した後,おおむね一 定電流が観測される。(a)の場合は(b)よりも大きい。(c)で は流れない。(c)に扔いて観測される初期のバルス電流は回 路に存在する漂遊容量を充電する電流である。この電流は (a)や(b)にも同様に存在する。

〈3.2〉ターゲット面積およびターゲット距離のモデュレータ電 压に与える影響 従来のモデュレータを用いてターゲット 面積やアーク源とターゲット間の距離によってターゲット 印加電圧が変化する様子を観測した。プラズマ源は接点開 離式のトリガ放電により起動される金属蒸気ア一クであ る。図5，図6は，それそれ、アーク源とターゲット間の 距離を $150 \mathrm{~mm}$ としたとき，ターゲット直径 $80 \mathrm{~mm}$ と $100 \mathrm{~mm}$ の 場合の印加電圧波形を示す。図中には参考のために定抵抗 (抵抗值 $15 \mathrm{k} \Omega$ )を負荷として用いたときの電圧波形を破線 にて表す。図5および図6から電圧波形の立ち上がり特性 が距離やターゲットの大きさに大きく影響されていること がわかる。

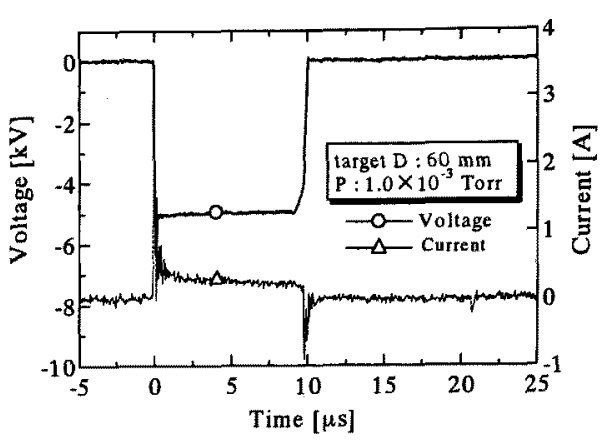

(a)Target diameter:60 $\mathrm{mm}$

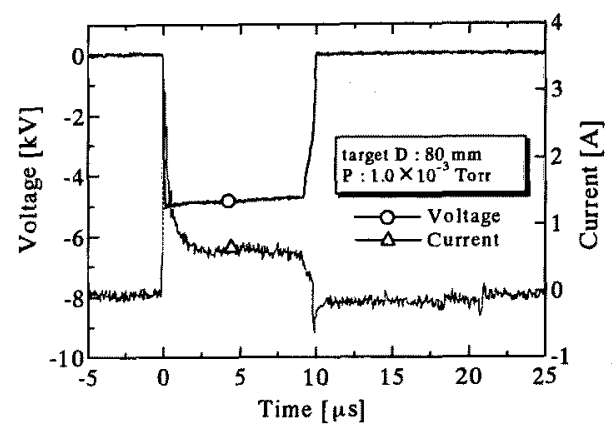

(b) Target diameter:80mm

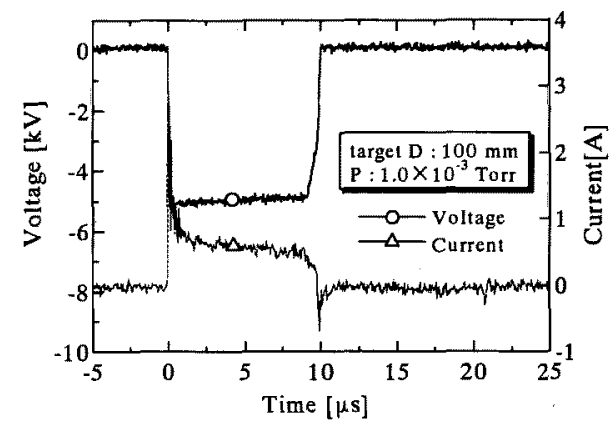

(c)Target diameter: $100 \mathrm{~mm}$

図7開発されたモデュレータによるターゲット印加電圧波 形およびターゲット電流(ターゲットーアーク源間距離 $400 \mathrm{~mm}$ )

Fig. 7 Waveforms of target applied voltage and current through the target (Distance between target and arc source :400mm)

ターゲットパラメータによる印加電圧の変化は,モデュ レータが有限の出カインピーダンスを持つこと,ターゲッ 卜周辺の漂避容量やシース容量が変化するためである。し かるにモデュレータ出力インピーダンスが無視できる程度 に小さくなればモデュレータの出力電圧のパルス幅に対し て十分に小さい時定数となリ，このような波形の変化は生 じない。

四5の昇圧用トランスを用いる場合はモデュレータ出力 インピーダンスにより電気的特性に違いが生ずる典型例で ある。モデュレータ出力が変圧器を介さないでターゲット に直接接続される場合,系は比較的低インピーダンスとな り, 図5〜図7で見られたほど大きな電圧波形の変動は起 こらないと考元られる。しかるに，図 5 や図 6 の結果から ターゲットの大きさによって容量が変化する事実はプラズ 
マイオン注入において大型物, 小物大量ターゲットへの均 一注入の目的のためには系が高インピーダンスとなること は避ける必要がある。すなわち, プラズマイオン注入にお いて複雑形状物に対する処理を行う場合にはモデュレータ のインピーダンスを小さくし,かつターゲット形状や曲率 ,配置などによるターゲット周囲の容量(接地容量が大部分 と考えられる)をできるだけ少なくするような余裕のある 設計が必要と結論される。

一般に, モデュレータの設計, 組み立てを行う場合, モ デュレータ内に出力波形調整用の回路素子の挿入が行われ る。場合によってはダイオードによる反転電圧の抑止も行 われる。さらにモデュレータおよび全系統の保護対策とし てクロバースイッチや真空管系においてはブランキング回 路が設けられる。これらの保護対策を講じた場合,接地に対 する漏れ抵抗等が存在しており,接地系への電流の漏洩が あり、電圧波形を歪ませる。

以上よりモデュレータ出力電圧は負荷であるターゲット や回路定数(漂遊容量, 回路インピーダンス)の影響を受け る。特に, 印加電圧の波尾に大きな変化が現れること, 立 ち上がりについても若干の違いが発生することがわかっ た。

\section{4. 本研究により開発された負荷に影響されないモ デュレータ特性}

図7は開発されたモデュレータによるターゲット印加電 圧波形およびターゲット電流を示す。ここではターゲット の直径を $60 \mathrm{~mm}$ から $100 \mathrm{~mm}$ まで変化させた。図より明らかな ようにターゲット直径の変化によって電圧特性には何らの 変化が見られず,プラズマやターゲットの影響をほとんど 受けない特性となっていることがわかる。初期の電流は1 $\mu$ $\mathrm{s}$ 以内の短時間で急峻に立ち上がり, 速やかに定常電流に 達する。Lieberman ${ }^{1)}$ の指摘する空間電荷制限電流が印加 電圧の $3 / 2$ 乗に比例するチャイルド・ラングミュア則を満 足する波形を呈しているとも考えられる。立下りについて も同様に速やかな時間推移が見られる。このように開発さ れたモデュレータは低出力インピーダンスであって,かつ 電荷放出用に設けられた閉スイッチ素子の動作により,従 来から問題とされてきた負荷による波形の変化をなくすこ とができる。

以上より,本研究において開発されたプラズマイオン注 入用パルスモデュレータは負荷の影響を受けない電圧特性 となっており,種々の曲率を有する三次元形状物への均一 なイオン注入に対し有効と考えられる。

\section{5. むすび}

負荷に影響されないプラズマイオン注入用モデュレータ の開発を行った。パラメータとしてはプラズマ源(金属蒸
気粒子プラズマ源)からの距離やターゲットの大きさを変 えた場合の特性の変化についてターゲット印加電圧および ターゲット電流波形の時間変化を観測した。開発されたモ デュレータは所定のパルス幅を得るために負荷側を短絡す る機能を持つとともに低インピーダンス形にて構成されて いる。

比較のために比較的インピーダンスが高い構成となる昇 圧トランスを持つモデュレータにおいても特性の観測を 行った。その結果, モデュレータ回路中に存在するイン ピーダンスによりターゲット印加電圧波形は大きく変化す る。またターゲットの大きさは真空容器との間の容量など 電気パラメータの変化を引き起こし, 電圧波形に大きく影 響する。プラズマイオン注入において均一注入をもたらす ためには負荷による特性の変動を低減する必要性がある。

開発されたモデュレー夕は負荷に関係なく,同一の波形 を呈することが明らかにされ，三次元形状物への均一イオ ン注入に対し，有効であると考えられる。

(平成 12 年 9 月 4 日受付, 平成 12 年 12 月 15 日再受付)

\section{文献}

[1]M.A.Li eberman:J.Appl.Phys. ,66, 2926-1919(1989)

[2]天野, 行村 \& 政宗: 電気学会プラズマ研究会資料, 資 料番号EP-99-49(1999)

[3] G.Bohm \& R.Gunzel:J.Vac.Sci.Tschnol. B, 12(2), 821822(1994)

[4]J.T.Scheuer, K.C.Walter, R.A.Adler \& W.G.Horne: Surface and Coatings Technology, 93, 192-196(1997)

[5]G.A.Collins, K.T.Short \& J.Tendys: Surface and Coatings Technology, 93, 181-187(1997)

[6]K.Yukimura, K.Ohno, M.Koto, S.Kurooka, Y.Suzuki, A.Kinomura, A.Chayahara \& Y.Horino: Surface and Coatings Technology, 103-104, 252-256(1998)

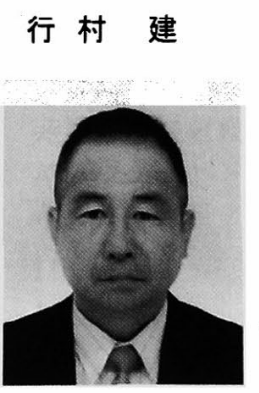

(正員) 1948 年 2 月 11 日生まれ。 77 年 3 月同志社大学工学研究科博士課程修了。 同年 4 月同大学工学部電気工学科助手, 79 年4月同専任講師、86年4月同助教授, 92 年 4 月同教授、現在に至る。工学博士。 主として、エキシマレーザ, 真空紫外光, パルスイオン注入などパルスパワーに関 する研究に従事。IEEE, 日本物理学会、応 用物理学会、プラズマ・核融合学会会員 レーザー学会会員 


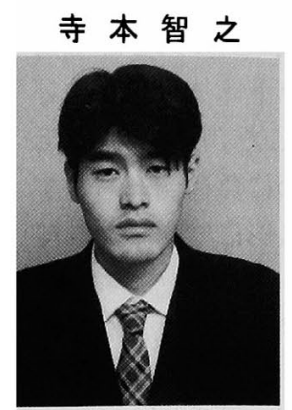

（学生員） 1977年2月 24日生まれ。1999 年 3 月同志社大学工学部電気工学科卒

業。同年 4 月同大学大学院工学研究科電 気工学専攻博士前期課程入学, 現在に至 る。主にイオン注入に関する研究に従 事。

\section{久世英司}

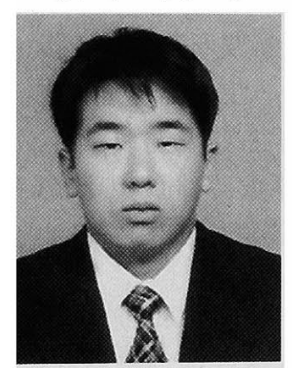

(学生員) 1977 年 6 月 7 日生まれ。2000 年 3 月同志社大学工学部電気工学科卒

業。同年 4 月同大学大学院工学研究科電 気工学専攻博士前期課程入学, 現在に至 る。主にイオン注入に関する研究に従 事。
昖永浩一

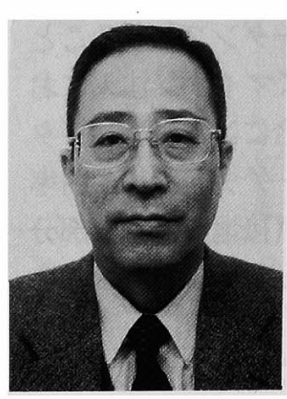

（正員）1943 年生。1967 年 3 月工学院大 学電子工学科卒業。1986年春日電機株式 会社技術部長, 高圧安定化電源機器の開 発に従事。1991年株式会社ハイデン研究 所代表取締役。高圧電源機器の開製造販 売に従事。 